\title{
Voice of Women in Indian English Literature ${ }^{1}$
}

\author{
Miss Madhuri V. Brahmane, Research Scholar, Gondwana University, \\ Gadchiroli, Maharashtra, India.
}

\begin{abstract}
This article is a humble attempt to deal with the state of women in a patriarchal society from the Vedic period to modern contemporary society. On the one hand, a woman is extolled to the heights of heaven by epitomizing her as a goddess, on the other hand, she is damned as an abla, a weakling who depends upon man for her existence and sustenance. The article traces the paradigm shift where a woman emerges despite all obstacles to hold her own identity in personal and professional life. Here woman is not put vis-a-vis man but woman is no more an accessory to man rather a companion, a life partner who is equal to him in every respect.
\end{abstract}

\section{INTRODUCTION}

From time immemorial India has predominantly been a patriarchal society. Man occupied a prominent place in every sphere of life leaving woman as a fragile creature to depend upon him for everything beginning from her existence to her sustenance. In such a circumstance, a woman's struggle in a male dominated society can be but easily fathomed. She was considered good for nothing when it came to do something intellectual or artistic. Going to school or reading and writing were not something she was capable of. Her only work was to bring forth children, rear them up and look after household works. Operating with such background, it was inconceivable that women were able to think, study or able to make decisions, could express themselves in the form of speech, poetry, story telling, art etc. A. Sinha opines, "Women in India are, by and large victim of social, economic and political exploitation"2.

Thanks to the British rule in India, it became a blessing in disguise for it gave glimpses of possibilities that women could be allowed to obtain formal or innovative education. In the midst of such inner struggle, India found a prophet in Raja Ram Mohan Roy who being inspired by the English education and their world planned to bring about a change in the condition of women in India. Firoz Alam writes, "Ram Mohan Roy was a man of intellect and foresight. He was aware that the English language was key to progress"3. His contributions must be lauded because he was convinced that if society has to be transformed, to uphold the dignity of women and their emancipation is obligatory rather than imaginative. Roy, therefore, asked the women "To come out of the four walls of their homes and acquire knowledge of the modern world. He advocated widow remarriage and was instrumental in propagating against one more social evil like child marriage" ${ }^{\text {. }}$.

1.1 General trends in classical literature

To depict a clear picture of an Indian woman and her role in the family, society, poetry, drama, philosophy, religion, art and literature one must delve deep into the timeline ever since India commenced recording its history and development in the form of writing. Nishikant Jha believes, "Women have certain characteristics gifted by nature, particularly physical and emotional, which are different from men in many ways" ${ }^{\prime 5}$. India has a history of world famous ancient civilization in Harappa ${ }^{6}$ and Mohenjodaro ${ }^{7}$. Boasting of

\footnotetext{
${ }^{1}$ The research scholar clarifies the use of the phrase Indian English literature because in India there are several state and regional languages each having an age old well developed literature of its own. In every literature one will find writings on women, but the Research Scholar's primary concern is to decipher writings on or by women in the context of English literature for it would be unthinkable to deal with all the literatures of the subcontinent. Paradoxically however, the Research Scholar will clearly surf through the Indian classical literatures and acknowledges that the influence of other literatures cannot totally be overlooked to depict the origin and development of one's argument.

${ }^{2}$ Ajit Kumar Sinha, New Dimensions of Women Empowerment, New Delhi: Deep \& Deep Publications Pvt. Ltd., 2008, p. xxvii.

${ }^{3}$ Firoz Alam, Great Indian Personalities, The World's Greats also, Delhi: Sahni Publications, 2011, p. 300.

${ }^{4}$ Ibid. p. 301.

${ }^{5}$ Nishikant Jha, "Women Empowerment", in “New Dimensions of Women Empowerment, New Delhi: Deep and Deep Publications Pvt. Ltd., 2008, p. 55.

${ }^{6}$ The site of the ancient city contains the ruins of a Bronze Age fortified city, which was part of the Cemetery H culture and the Indus Valley Civilization, centered in Sindhbad the Punjab. The city is believed to have had as many as 23,500 residents and occupied about 150 hectares (370 acres) with clay sculptured houses at its greatest 
such high profile civilizations, it is easy to deduce that a full-fledged literature on philosophy of life developed as early as $6^{\text {th }}$ century $\mathrm{BCE}^{8}$. In order to fathom the past, one must understand the present. This wisdom might fit in here when one argues in support of the emancipation of women in present day Indian society because it is important to understand her status in the past.

\subsubsection{The Vedas, the Puranas and the Upanishads ${ }^{9}$}

The Vedas, the Puranas and the Upanishads are the mirrors, as it were, that reflect the glorious past of Indian: its history, its civilization, its language and literature, philosophy and theology. The Vedic tradition ${ }^{10}$ has held a high regard for the qualities of a woman who is portrayed as the feminine embodiment of important qualities and powers. These forms include those of Lakshmi (the goddess of fortune and queen of Lord Vishnu), Sarsvati (the goddess of learning), Durga (the goddess of strength and power) ${ }^{11}$ and the like. There are others, during this period, who were seen as the examples of historical importance. They are Sati, Sita, Anasuya, Arundhatee, Draupadi, Queen Kunti ${ }^{12}$, etc.

However, all that glitters is not gold for in Manusmriti one reads, "The position of women in Hinduism is mixed and contradictory". Tripta Desai further confirms, "Around 300 BC the status of women began to decline. Probably dating to the beginning of Christian era, the Manusmriti affords glimpses into the severe restriction of women's activities and status. From AD 500 to AD 1800 more Smritis and Puranas were complied which further degraded the existence of women. The Vedic society was patriarchal. Gender equality was not promoted; woman was only to be ruled over but not a ruler. Her world was unsympathetically limited. Woman was seen primarily as wife, mother and a sex object. A woman's role, as an individual thinker or one capable of articulating her ideas, was unthinkable. In case she did express her thoughts and feelings, they were overlooked as though they amounted to nothing. These are some of the reasons the women refrained themselves as intellectual writers or those who in anyway contribute to a thought provoking idea in a male dominated ambience.

\subsubsection{Classical Sanskrit ${ }^{13}$ literature}

Sanskrit served as threefold language: sacred, literary and philosophical, to Hinduism, Buddhism, Sikhism and Jainism. As such, most of the literary masterpieces were expressed in Sanskrit. For example,

extent during the Mature Harappan phase (2600-1900 BC), which is considered large for its time. (Cf. HarappaWikipedia, the free encyclopedia, (http//en.m.wikipedia.org as on 21.04.2016).

${ }^{7}$ Mohenjodaro is an archeological site in the province of Sindh, Pakistan. Built around 2500 BCE, it was one of the largest settlements of the ancient Indus Valley Civilization, one of the world's earliest major urban settlements, contemporaneous with the civilizations of ancient Egypt, Mesopotamia, Miona (Crete), and Norte Chico (Cf. Mohenjo-daro-Wikipedia, the free encyclopedia, (http//en.m.wikipedia.org as on 21.04.2016).

${ }^{8}$ Ram Dev Shastri, Glimpses of World Religions, New Delhi: Mohit Publications, 2009, pp. 17-18.

${ }^{9}$ The Indologists hold that the Vedas are a large corpus of texts originating in Ancient India. They form the oldest layer of Sanskrit literature and the oldest sacred texts of Hindusim. The term Veda refers to the Samhitas (collection of mantras or chants) of the four canonical Vedas (Rigveda, Yajurveda, Samveda and Atharvaveda). The Vedic perios lasts for about a millennium, spanning the Late Bronze Age and the Iron Age. Gavin Flood opines that Rigveda was compiled as early as $1500 \mathrm{BCE}$ and continued over a period of several centuries. The Upanishads, whereas, are regarded as part of the Vedas and as such form part of the Hindu Scriptures. The Upanishads are known as Vedanta and do not belong to a particular period of Sanskrit literature. The oldest, such as Brahadaranyaka, Chandogya and Jaminiya date to the late Brahmana period, i.e., mid first millennium BCE, while the youngest were composed in the medieval or even the early modern period (Ibid., pp. 15-28).

${ }^{10}$ Tripta Desai holds that $2500 \mathrm{BC}$ to $1500 \mathrm{Bc}$ can be accepted as the Vedic Age. The four Vedas of the Arans, of which Rigveda is the oldest and the most revered, were composed around these years. The period from 1500 $\mathrm{BC}$ to $500 \mathrm{BC}$ can be regarded as one of the Brahmanas and Upanishads, commentaries on, and addendums to the Vedas. When the Aryans, or the Indo-European tribe, entered India around $2500 \mathrm{BC}$ and began advancing across Jamuna and Gangetic valley to the East near Bengal, many native cults, with their gods and goddesses came to be incorporated into the religion of Vedas. From $500 \mathrm{BC}$ to AD 500 can be approximated as the period of the Sutras, early Smritis, the Epics of Ramayana and Mahabharata and the early Puranas (Cf. Tripta Desai, Women in India, New Delhi: Munshiram Manoharlal Publishers Pvt. Ltd. 1997, p. 3).

${ }^{11}$ Stephen Knapp, Women in Vedic culture, Stephen-Knapp.com as on 21.04.2016.

12 Ibid.

${ }^{13}$ The Sanskrit language took form in North-West India during the second millennium before our era. It is a detached branch of the linguistic group which has been given the name Indo-Iranian, which in turn derives from the mother language Indo-European. In a distinctly archaic form, rich in noun and verb structures which are yet ill coordinated, Sanskrit was first used for literary expression in the Veda (Cf. Louis Renu, The Civilization in Ancient India, New Delhi: Munshi Manoharlal Publications Pvt. Ltd, 1997, p. 8.

DOI: 10.9790/0837-2108032834 $\quad$ www.iosrjournals.org $\quad 29 \mid$ Page


Kalidasa, a famous Sanskrit poet and dramatist in classical Sanskrit exposes woman not as an ideal selfabnegating Hindu wife sympathetic, witty, resourceful, and beautiful but someone unrecognized, forgotten and humiliated like Shakuntala ${ }^{14}$. Amaru, a scholar in Tamil literature and erotic poetry writer, portrayed women as complex human beings; they are continuously victims of circumstances who aren't authoritative. They are physically not strong and resilient as men hence cannot exercise any kinds of authority rather remain resourceful and amusing to their male counterparts ${ }^{15}$.

\subsubsection{Early Dravidian literature}

The Dravidian movement too is not immune from avoiding paradoxical condition in treatment of women. On the one hand, it extols woman as a Devdasi ${ }^{16}$ (Handmaid of the Lord) allowing them the freedom of expression on a public platform, on the other hand, woman is merely man's appendage ${ }^{17}$. To vindicate, it can be viewed that Sangam classics were written by 473 poets, among whom 30 were women, the famous poetess Avvaiyar being one of them. Although many women had actively participated in the Dravidian movement, not much has been written about them ${ }^{18}$.

\subsubsection{Medieval literature}

Medieval period could be seen as a watershed in terms of art, literature, poetry and drama although folk plays continued to entertain the audience. The most powerful trend of medieval Indian literature between 1000 and 1800 A.D. is devotional (Bhakti) poetry which dominates almost all the major languages of the country. India's middle ages brought about a very rich tradition of devotional literature of remarkable merit which dispels the superstitious assumption of a dark period of India's history ${ }^{19}$. The contribution of women writers in different languages during that period deserves special attention. However it did not offer solutions to any of the problems women face concerning their rights. Women writers like Ghosha, Lopamudra, Gargi, Maittreyi, Apala, Romasha, Brahmavadini, wrote short lyrics or poems of devotional fervor of metaphysical depth and with a spirit of dedication and utmost sincerity. Behind their mysticism and metaphysics is a divine sadness. They depicted every wound imposed by life into a poem ${ }^{20}$.

\subsubsection{Modern Indian literature}

The dawn of the new era of modern Indian literatures may be said to ignite in the late nineteenth century. In the writings of this time, the impact of Western civilization, the rise of political consciousness, and the change in society was perceptible. A large number of writers made synthesis between Indianization and Westernization in their search for a national ideology. In the meantime, the Indian feminism too advanced by the stimuli of Western feminism, however it took slightly different route from that of the West. All these attitudes were combined to bring about the renaissance in 19th century India. Antonia Navarro holds, "The majority of these novels depict the psychological suffering of the frustrated housewife, this subject matter often been considered superficial compared to the depiction of repressed and oppressed lives of women of the lower classes" $^{21}$. Reformers supported female education in India, believing that social evils could be eliminated through the education of the women. Indian women writers gave a new dimension to the Indian literature, in that they vented their deep seated feelings by way of art and literature. Contemporary writers like, Anita Desai, Manju Kapur, Shashi Deshpande, Shobha De, Jhumpa Lahiri, Kamla Markandaya, Ruth Prawar Jhabvala, Krishna Udayasankar, Chitra Banerjee Divakaruni, Arundhati Roy etc. have challenged the society for metamorphosis of women's status ${ }^{22}$.

\subsubsection{Emergence of nationalism}

Indian writers like Bankim Chandra Chatterjee ${ }^{23}$, Rabindra Nath Tagore ${ }^{24}$, Mahatma Gandhi, Pandit Jawaharlal Nehru ${ }^{25}$, Pt. Ramabai, Sarojini Naidu, to name a few, have made use of this newly acquired concept

\footnotetext{
${ }^{14}$ Kalidasa-Wikipedia, the free encyclopedia, (http//en.m.wikipedia.org as on 22.04.2016).

${ }^{15}$ Amaru Shakta-Wikipedia, the free encyclopedia, (http//en.m.wikipedia.org as on 22.04.2016).

${ }^{16}$ Dravidian peoples-Wikipedia, the free encyclopedia, (http://en.m.wikipedia.org as on 22.04.2016)

${ }^{17}$ Thomas Jayseelan, Women rights and law, New Delhi: Indian Social Institute, 2002, p.8.

${ }^{18}$ Menstruating Women/Menstruating Goddesses: Sites of Sacred (www.metaformia.org, as on 22.04.2016.

${ }^{19}$ Ramond Kerobin, Sant Daria Sahab, New Delhi: Gautam Prints, 2013, p. 2.

${ }^{20}$ Susie Tharu, Women writing in India, Vol. 1, New Delhi: Oxford University Press, 1991, p. 13.

${ }^{21}$ Antonia Navarro-Tejero, Modern Indian women writers in English, (www.literature-study.online.com as on 24.04.2016).

${ }^{22}$ M. F. Patel, Feminism in contemporary Indian women writers, Jaipur: Avishkar Publishers, 1998, P. v.

${ }^{23}$ Bankim Chandra Chaterji was a patriot, poet and a novelist. In the field of literature, In West Bengal, he is ranked after Madhusudan Dutta. He tried to dismantle the barrier between the rich and the poor. He also wanted

DOI: 10.9790/0837-2108032834 $\quad$ www.iosrjournals.org $\quad 30 \mid$ Page
}


of nationalism to attack colonial rule. Rise of nationalism proved opportune for the women writers because in the name of nationalism, they could voice out the dormant oppression that had long been suppressed. Gandhiji was totally opposed to gender discrimination. He did not like Indian society's preference for a boy and general neglect of a girl child. He viewed, "Woman as the embodiment of sacrifice and ahimsha" 26 . This idea gradually spread in the country and many common women came out to join in the national struggle for freedom, freedom not only from British rule but also for freedom of expression within the country.

2.1 Emergence of women after independence

After independence, Indian English Literature has been growing rapidly both in quantity and quality. It began, through the momentous, outstanding, and vibrant contributions by the contemporary Indian writers as competent as the British, American, Australian, Canadian and African literature. The struggle for freedom was voiced in the form of writings. A great number of Indian writings are vehemently apprehensive about various ways and forms of oppression they undergo. This subjugation was both interior and exterior. Once treated as a solitary voice, is now audible in every sphere of life. Hence, having examined the role and the place of women from the earliest possible data in the first part, it is opportune to decipher where they stand in the era during and after the independence.

\subsubsection{Search for modernity and British impact}

The Indian English literature is a journey from nationalism to the search of nation. English education benefited the British for sure, but brought forth many social reforms and innovations to English literature paving the dawn of a new India. Writers like Sarojini Naidu ${ }^{27}$, Tagore, Sri Aurobindo ${ }^{28}$, through their lucid writings poured enthusiasm among the hearts of Indians. Sarojini Naidu tried to re-establish self-esteem within the women of India while Tagore filled the heart of the Indians with the sense of patriotism ${ }^{29}$. There emerged a champion of liberty in Raja Ram Mohan Roy who advocated the rights of women. He was determined to give women their proper place in the society. He acted as a bridge between India and England. His vision was to make India a new and modern country and Indians to become a virile new people. He abolished sati and advocated in favor of widow remarriage ${ }^{30}$. With his profound and pioneering fiction, Raja Ram enabled English

to break down the caste system in Hindu society. Despising the caste system Bankim wrote, "Due to the caste distinction grave differences had emerged between the higher and the lower castes, a thing unknown in the whole of the civilized world". Bankim also thought of national unity. He continued, "This unity in policy can only be acquired through the medium of English...for Sanskrit is now dead; the English language is the common ground for the communication between Punjabies and Bengalies. With this hope will be built the knot of Indian Union. Therefore, let the English spread as far as it can..." (Cf. Firoz Alam, op. cit., pp 238-241).

${ }^{24}$ Rabindranath Tagore was (1861-1941) was a poet, novelist, patriot and a philosopher. He was the first Asian to receive Nobel prize for literature in 1913 for Gitanjali. He is the writer of National Anthem of India and was also the exponent of Swadeshi. F. Alam writes, "Rabindranath Tagore was to India what Goethe was to Germany and Wordsworth to England. He stands as a literary landmark. Human relationship was another topic of his interest. His poems were inspired by the nationalist movements" (Cf. Firoz Alam, pp. 195-196).

${ }^{25}$ Jawaharlal Nehru was born in a wealthy and aristocratic Brahmin family in Allahabad on $14^{\text {th }}$ November, 1989. At the age of 15, Nehru was sent to England to pursue education in English language. He was deeply interested in literature, politics, economics and history. Nehru returned to India in 1912 and joined Allahabad High Court as a barrister. He joined his political career after meeting Mahatma Gandhi at Lucknow in 1916. (Cf. P. B. Rathod, Indian Political Thinkers, New Delhi: Commonwealth, 2006, pp. 174-175).

${ }^{26}$ Promilla Kapur, Empowering the Indian Woman, New Delhi: Publications Division, 2001, p.6.

${ }^{27}$ The name of Sarojini Naidu figures in the topmost level of nationalists fighting against the British to secure independence of the country. As an indefatigable worker of the Indian National Congress and a political stalwart, her name may be mentioned along with that of Gandhi, Nehru, Patel, Subhas Chandra Bose and Maulana Azad. (Cf. Santanu Ganguly, "Sarojini Naidu (1879-1949)", in Studies in Indian Poetry in English, Kolkata: Books Way, 2009, p. 73).

${ }^{28}$ Sri Aurobindo (Aug 15, 1872-Dec 5, 1950), later called Arvinda Ghosh, was an Indian nationalist, poet, writer, literary critic, philosopher and mystic. He attended an English school in Darjeeling but subsequently studied at St. Paul's School and Cambridge in England. He returned to India in 1893 at taught at Baroda college. On the eve of Calcutta Congress in 1906 he was first to declare complete autonomy from British control. Wrote articles on Passive Resistance and serialized his play Perseus the Deliverer in the Bande Matram. (Cf. Monisha Sarkar and Subh Brat Sarkar, "Sri Aurobindo (1872-1950)", in Studies in Indian Poetry in English, Kolkata: Books Way, 2009, p. 45).

${ }^{29}$ Firoz Alam, op. cit., p. 196.

30 Ibid., p. 301. 
readers to experience the spiritual depths of Indian culture. His writing is the voice of an ancient and insightful culture that speaks to the modern world ${ }^{31}$.

Nayantara Sahgal, Mulk Raj, Shashi Deshpande, Khushwant Singh, Kamala Markandaya, Gita Mehta etc. are a few examples who searched for alternatives to existing literary models making Indian modernity a mosaic. This also emerged as a new creative force of resistance. It resisted the injustice and cruelty of the colonizers and manifested what we often referred to as the literary resistance ${ }^{32}$.

\subsubsection{Indian literary scene after independence}

After independence, the Indian literature had an outstanding impact on the creative writing in various regional languages. Post-independence India did see a greater awareness on the part of the reading public as well as the government of the existence of many more and wealthier languages and literatures, outside the limited margin of one's own mother-tongue or province. 'The partition of India' did sear an emotional scar in the souls of many writers, mostly in Punjabi, Urdu, Hindi and Bengali literatures. Many moving short stories and poems have been written on this theme by authors like Amrita Pritam, Kartar Singh Duggal, Krishan Chander, Khushwant Singh, Premendra Mitra, Arundhati Roy and Manoj Basu, to mention a few names ${ }^{33}$.

The martyrdom of Mahatma Gandhi was another such event, about which soul-stirring poems were written by Vallathol Narayana Menon, Bhai Vir Singh, Shivmangal Singh Suman and others. So also things like identity crisis of the writers, the clash between traditional cultures and western modernity, the concept of experimentation under the Western influence is mostly found in the writings during those days. It emerged as a chase for new values and their sources. Several poets revealed the poet's solitary struggle in opposition to the mounting crisis of uprooted identity. They wrote political poetry on the theme of agony and struggle. It was a poetry of commitment. Literature now enthused to the downtrodden and the exploited. 'Likewise the woman has been a focus of many literary works, she is no longer a paragon of virtue and chastity to the extolled poets and philosophers. The Indian women are now making a stir out of their placed solecism. Arising political and social conscious in a fertile milieu have brought them out into the open protest against decimation, dowry, rape and exploitation. The woman in Indian novel now reflects the shift in the sensibility as a writer and reader ${ }^{34}$.

\subsubsection{Contemporary literature}

In today's ultra adhunika (post-modern) era, the effort of the contemporary writers is to be natural, to be Indian, to be socially conscious and to be near to the common man. Indian writers like Salman Rushdie, Shahshi Tharoor or Amitav Ghosh came out of the shadow of British English only to decorate the Indianized English distinctively ${ }^{35}$. Also the regional languages were freely used in the prose forms; thus breaking, restructuring and adding a new twist and dimension to the traditional narrative patterns. Hindi, Gujarati, Bengali, Telugu, Tamil, Kannada, Marathi writers followed to the 'modern' and 'postmodern' idiom of writing. For instance, Mulk Raj Anand's work is supplied with Hindi and Punjabi words like 'haanaa', 'saalam-huzoor', 'shabash-shabash'. The most path breaking of all, however, is Arundhati Roy's use of untranslated Malayalam words in day to day conversations in her 'The God of Small Things' like 'chacko sir vannu', 'she is very beautiful sundarikutty', 'oower, orkunniley, kushambi ${ }^{36}$.

\subsection{Women in search of greater autonomy and freedom}

The impact of the English Literature reflected in the regional literatures of the subcontinent introducing several important changes in women's personal and professional life. Prolific Indian female authors in English like Kamala Markandaya, Nayantara Sahgal, Anita Desai, and Shashi Deshpande gave rise to the emergence of feminism in India ${ }^{37}$. Emancipatory women's writing has arisen sturdily in all Indian languages, seeking to subvert the man-dominated social order, forging revisionary myths and counter-metaphors by women writers like Kamala Das (Malayalam, English), Krishna Sobti (Hindi), Ashapurna Devi (Bengali), Rajam Krishnan (Tamil) and others ${ }^{38}$. A large number of writers are in the process of identifying a pattern of problem-solving

\footnotetext{
${ }^{31}$ Robert L. Hardgrave, Word as Mantra: the Art of Raja Rao. Austin: University of Texas, 1998, p. 60.

32 Jasvant Rathod, "The Indian literature in English: a journey from nationalism to search of nation", Researchgate, Vol. 1, Multi Disciplinary Edu Global Quest, October 2012, pp. 156-158.

${ }^{33}$ M. F. Patel, please see the left cover flap.

${ }^{34}$ Shanta Krishnaswamy, The woman in Indian fiction in English, New Delhi: Ashish Publishing House, 2001, pp. 53-56.

${ }^{35}$ M. F. Patel, op. cit., p. vi.

${ }^{36}$ Arundhati Roy, The God of Small Things, London : Penguin Books, 1997, pp. 304-340.

${ }^{37}$ Shubha Mukherjee, "Anita Desai and her Women," in Feminism in Contemporary Indian Women Writers, M. F. Patel (ed.), pp. 51-59.

${ }^{38}$ Amar Nath Shrivastava, The Champion of Indian Fiction, New Delhi: Mohit Publication, 2011, p. 27.

DOI: 10.9790/0837-2108032834 www.iosrjournals.org 32 |Page
}


within the traditional system and sustain an indigenous process of renewal. English is no more a colonial language, writers are aware of their inheritance, complexity and uniqueness, and it is expressed in their work naturally. Feminism is an ideology that opposes the political, economic and cultural demotion of women to positions of inferiority. Feminists' condition in India have an unlike dispensation than that of Western feminism in that the Indian society has always been extremely hierarchical. There is also quite a lot of hierarchy within the family pertaining age, sex and ordinal position, genial and fine bond or within the community referring to the caste lineage, education, occupation and relationship with ruling power etc. have been upheld very sternly. In India the history of the modern Western feminist movements is divided into three "waves". Each wave is categorized by means of looking at the same feminist issues in a different prospective ${ }^{39}$.

\subsubsection{The first-wave (1850-1915)}

It refers to the feminist movement that occurred in between 1850-1915. Suma Chitnis, an eminent sociologist, from Maharashtra recalls how the most typical features of this movement was initiated by men like Raja Ram Mohan Roy along with other reformers like Ishwarchandra Vidya Sagar, Keshav Chandra Sen, Matahari, Phule, Agarkar, Ranade, Tagore, Madan Mohan Malviya, Maharshi Krave and the women joined the crusade $^{40}$.

\subsubsection{Second Wave (1915-1947)}

During this period the battle against colonial rule was strengthened. Self-government became the preeminent cause. Gandhi legitimized and extended Indian women's public activities by calling them into the nonviolent civil disobedience movement against the British Raj. He dignified their feminine roles of caring, selfabnegation, sacrifice and tolerance; and impressed a position for those in the public field. Peasant women played a vital role in the rural Satyagrahas of Borsad and Bardoli. Women organizations like All India Women's Conference (AIWC) and the National Federation of Indian Women (NFIW) occurred. Women were dealing with issues involving to the scope of women's political participation, women's franchise, communal awards, and leadership roles in political parties. Under the leadership of Mahatma Gandhi, the nationalist and anti-colonialist freedom movement made the mass utilization of women to a fundamental part of Indian nationalism ${ }^{41}$.

\subsubsection{The third-wave (Post-independence-1947)}

Prior to independence, most feminists accepted the sexual division within the labor force. Nevertheless, feminists of the 1970s dared to raise their voice against the inequalities and battled to reverse them. These included unequal wages for women, demotion of women to 'unskilled' spheres of work, and limiting women as a reserve army. The fruition is seen as in 1966 Indira Gandhi became the first female Prime Minister of India. She served as prime minister of India for three consecutive terms ${ }^{42}$.

\section{CONCLUSION}

The patriarchal society prevalent in India had jeopardized and crippled the Indian mind to such an extent that men thought that no woman was found worthy of education. Men considered themselves independent, superior and even almighty. A man was invariably the breadwinner whereas the woman was supposed only to share what the man had earned with his sweat and blood. It looked as though, a man's world would continue even without a woman. Traits are visible, that in ancient India, women though having an enormous potential, were being unutilized and underutilized. Customarily women were treated as 'abla' which means a weakling, dependent on men and confined to the four walls. Thanks to some courageous and daring women, today the table is being turned upside down. As the civilization changes, the societies go through transformation, Indian women too are on a crossroad not to prove themselves but to get out of the shadows of men. Today, women dare to walk shoulder to shoulder with men. They are ready to expose the splendour and beauty of the world in which they live have a better role to play than remaining mere spectators within the four walls of the house. The men who thought they were superior to women have now recognized the potentialities of women; women are not just spectators but partners and coworkers. Women are not inferior to man in rank or performance in anyway. This is true in the field of literature too.

\section{BIBLIOGRAPHY}

Primary sources

Alam, Firoz. Great Indian Personalities, The World's Greats also, Delhi: Sahni Publications, 2011.

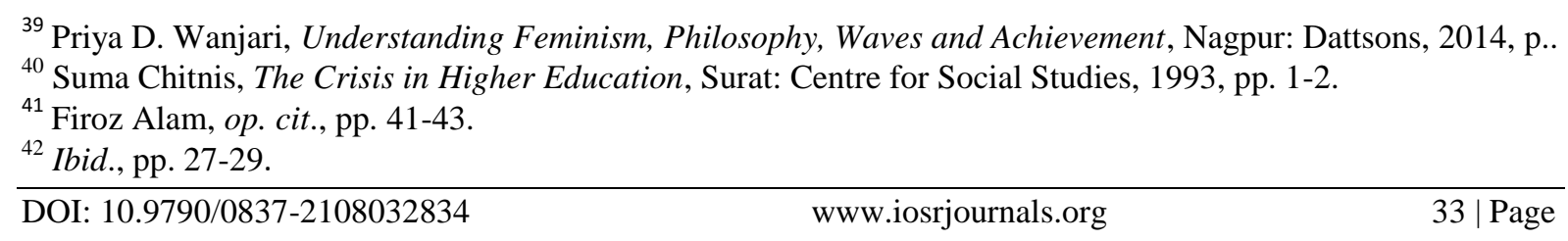


Chitnis, Suma. The Crisis in Higher Education, Surat: Centre for Social Studies, 1993.

[1] Desai, Tripta. Women in India, New Delhi: MunshiramManoharlal Publishers Pvt. Ltd. 1997.

[2] Ganguly, Santanu. "Sarojini Naidu (1879-1949)", in Studies in Indian Poetry in English, Kolkata: Books Way, 2009.

[3] Hardgrave, Robert L. Word as Mantra: the Art of Raja Rao. Austin: University of Texas, 1998.

[4] Jeyaseelan, Thomas. Women Rights and Law. New Delhi: Indian Social Institute, 2002.

[5] Jha, Nishikant. "Woman Empowerment", in New Dimensions of Women Empowerment. New Delhi: Deep \& Deep Publications Pvt. Ltd., 2008.

[6] Kapur, Promilla. Empowering the Indian Woman, New Delhi: Publications Division, 2001.

[7] Kerobin, Raymond. Sant Daria Sahab, New Delhi: Gautam Prints, 2013.

[8] Krishnaswamy, Shantha. The Woman in Indian Fiction in English. New Delhi: Ashish Publishing House, 2001.

[9] Lalita, Susie Tharu and K., ed. Women Writing in India. Vol. I. New Delhi: Oxford University Press, 1991.

[10] Rathod, Jasvant. "The Indian Literature in English: a journey from Nationalism to search of nation." Researchgate. Vol. 1. Multi Disciplinary Edu Global Quest, October 2012.

[11] Rathod, P. B. Indian Political Thinkers, New Delhi: Commonwealth, 2006.

[12] Sarkar, Monisha and Sarkar, Subh Brat. "Sri Aurobindo (1872-1950)", in Studies in Indian Poetry in English, Kolkata: Books Way, 2009, p. 45.

[13] Shastri, Ram Dev. Glimpses of World Religions, New Delhi: Mohit Publications, 2009.

[14] Sinha, Ajit Kumar. New Dimensions of Women Empowerment. New Delhi: Deep \& Deep Publications Pvt. Ltd., 2008.

[15] Shrivastava, Amar Nath. The Champion of Indian Fiction, New Delhi: Mohit Publication, 2011.

[16] Secondary source

[17] Amaru Shakta- Wikipedia, the free encyclopedia, (https://en.m.wikipedia.org), (as referred on 22.04.2016).

[18] Dravidian peoples- Wikipedia, the free encyclopedia, (https://en.m.wikipedia.org), (as referred on 21.04.2016)

[19] Harappa- Wikipedia, the free encyclopedia, https//en.mwikipedia.org, (as referred on 21.04.2016).

[20] Kalidasa-Wikipedia, the free encyclopedia (https://en.m.wikipedia.org), (as referred on 22.04.2016).

[21] Knapp, Stephen. Women in Vedic culture, Stephen-Knapp.com, (as referred on 21.04.2016).

[22] Menstruating Women/ Menstruating Goddesses: Sites of Sacred (www.metaformia.org), (as referred on 22.04.2016).

[23] Mohenjo-daro-Wikipedia, the free encyclopedia, https//en.mwikipedia.org, (as referred on 21.04.2016).

[24] Navarro-Tejero, Antonia. Modern Indian Women Writers in English. www.literature -study-online.com. (as referred on 24.04.2016)

[25] Women in Hinduism-Wikipedia, the free encyclopedia, (https://en.m.wikipedia.org), (as referred on 21.04.2016) 